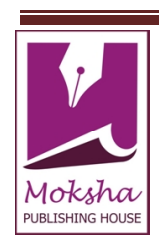

INTERNATIONAL RESEARCH JOURNAL OF PHARMACY

www.irjponline.com

ISSN $2230-8407$

Research Article

\title{
FTIR ANALYSIS FOR SCREENING VARIATION IN ANTIMICROBIAL ACTIVITY OF FRESH AND DRIED LEAF EXTRACT OF RHYNCHOSTYLIS RETUSA: A THREATENED ORCHID SPECIES OF ASSAM, NORTH EAST INDIA
}

\author{
Das Amar Jyoti ${ }^{1}$, Athar Mohammad ${ }^{3}$, Kumar Manoj $^{1}$ and Kumar Rajesh ${ }^{1,2 *}$ \\ ${ }^{1}$ Department of Environmental Microbiology, School for Environmental Sciences, Babasaheb Bhimrao Ambedkar \\ (A Central) University, Vidya Vihar, Raibareli Road, Lucknow, India \\ ${ }^{2}$ Department of Microbiology, College of Basic Sciences and Humanities, G. B. Pant University of Agriculture and \\ Technology, Pantnagar, India \\ ${ }^{3}$ Department of Applied Chemistry, School of Physical Sciences; Babasaheb Bhimrao Ambedkar University (A Central \\ University); Vidya Vihar, Lucknow, India \\ *Corresponding Author Email: rajesh_skumar@yahoo.co.in
}

Article Received on: 14/05/13 Revised on: 05/06/13 Approved for publication: 11/07/13

DOI: $10.7897 / 2230-8407.04741$

IRJP is an official publication of Moksha Publishing House. Website: www.mokshaph.com

(C) All rights reserved.

\section{ABSTRACT}

This study was designed to analyze FTIR data to evaluate the role of functional groups in variation of antimicrobial potential of fresh and dried leaf extract of Rhynchostylis retusa a threatened orchid species of Assam, North East India. Aqueous fresh and dried leaves extracts of Rhynchostylis retusa were investigated for antibacterial activity (zone of inhibition) against Staphylococcus aureus, Pseudomonas aeruginosa, Escherichia coli and Salmonella typhi. Maximum antibacterial activity was exhibited by fresh leaves extract (22.0, 20.8 and 22.4, 20.0 mm against Staphylococcus aureus, Pseudomonas aeruginosa, Escherichia coli and Salmonella typhi respectively) while dried leaf extract, showed very less activity. The leaf extracts were further evaluated for FTIR spectroscopy. The results in the present study suggest that Rhynchostylis retusa leaf medicinal phytoconstituents remains active only in the presence of some functional groups which are present in fresh leaves.

Keywords: Rhynchostylis retusa, antimicrobial activity, Assam, FTIR.

\section{INTRODUCTION}

Medicinal plants are an important source for the natural composite material that act as new anti infectious agents and can be used for verification of pharmacological activities. They have been used for thousands of years for the treatment of the diseases ${ }^{1}$. These pharmacological activities are due to the phyto-constituents present in the plants. Many studies indicate that in some plants there are substances such as alkaloids, unsaturated long chain aldehydes, peptides, some essential oils, ethanol, phenols, water, chloroform, methanol and butanol soluble compounds. These plants therefore emerged as sources of compounds with potentially significant therapeutic application against human pathogens, including fungi, bacteria and virus ${ }^{2-4}$. Fourier transform infrared spectrometry (FTIR) is a physico-chemical analytical technique employed to determine the structure of unknown composition and the intensity of the absorption spectra associated with molecular composition or content of the chemical group ${ }^{5-6}$. By attaining IR spectra from plant samples, it might be possible to detect the minor changes of primary and secondary metabolites ${ }^{7}$. Rhynchostylis retusa (Foxtail Orchid), is the state flower of Assam and is known as Kapau phool in Assamese. It is an endangered orchid species that grows in moist forest areas in the Western Ghats, north east India and the Himalayas and blossoms during monsoon. In dense tropical evergreen forests, often sunlight does not permeate the dense canopy. Hence, plants like orchids grow high up on trees, thereby increasing the chances of receiving sunlight, so critical for them to make food through photosynthesis. As a result, they act as epiphytes. In Assam, fox tail orchid is often used for various cultural activities (Bihu, marriage etc). The fresh leaves or their extract traditionally is used to treat rheumatic disease, ear pain, blood dysentery, skin diseases and external inflammations. Although, this plant is traditionally applicable for the treatment of several diseases, but to our knowledge, there are no systematic scientific studies on it. Today there is a realization to preserve the enormous wisdom, traditional knowledge and also the cultures associated with them ${ }^{8}$.

The present study was carried out to establish the role of FTIR spectra in screening the antimicrobial activity of fresh and dried leaf extract of Rhynchostylis retusa against selected human pathogens.

\section{MATERIALS AND METHODS}

\section{Collection and Sterilization of Plant Materials}

Plants were collected from Darikal gaon village of Sonitpur district in Assam, North East India. The disease free and fresh plants were selected. About $100 \mathrm{~g}$ of fresh and dried leaves were taken for each solvent extraction. They were washed with distilled water for three times. Then, surface sterilized with $0.1 \%$ mercuric chloride for 20 seconds. Again the leaves were washed thoroughly with distilled water for three times ${ }^{10}$.

\section{Preparation of Extracts}

Extracts were prepared by following the method of Oyagade, $1998^{11}$. The fresh water extracts were prepared by suspending $50 \mathrm{~g}$ of the each finely blended fresh and dried leaves in 100 $\mathrm{ml}$ of distilled water in different beaker. This was then agitated using the blender after which another $150 \mathrm{ml}$ of distilled water was added. The mixture were stirred every 3 minutes for 30 minutes and then allowed to stand for $24 \mathrm{~h}$. The extract were then decanted and filtered through a Whatman filter paper No.1. The filtrate were then concentrated with the rotary evaporator at $45^{\circ} \mathrm{C}$. This extract was then stored in refrigerator at $4^{\circ} \mathrm{C}$ until use. 
Test Organisms

The bacterial spp. used for the test were Staphylococcus aureus, Escherichia coli, Pseudomonas aeruginosa and Salmonella typhi. All the cultures were procured from Departmental Gene Pool.

\section{Antimicrobial Disc Preparation}

The blank discs of about $6 \mathrm{~mm}$ diameter were made from Whatman's No.1 filter paper using a paper puncher. Batches of 100 discs were transferred into Bijou bottles and sterilized in the oven at $121^{\mathrm{C}} \mathrm{C}$ for 15 minutes. After sterilization, blank discs were separately impregnated with each of the leaf extract.

\section{Antimicrobial Bioassay}

The bacteria were grown in nutrient broth, incubated at $37^{\circ} \mathrm{C}$ overnight. One $\mathrm{ml}$ of the broth culture of each bacterium was spread over the nutrient agar taken in glass petri-dishes aseptically. The extract impregnated discs, blank paper discs impregnated with sterile solvents (distilled water) were placed on the inoculated nutrient agar in the Petri dishes and incubated at $37^{\circ} \mathrm{C}$. After $24 \mathrm{~h}$ incubation, the zones of inhibition of bacterial growth around the discs were measured. The experiments were repeated thrice. All values are expressed as means \pm standard deviation.

\section{FTIR Analysis of the Extract}

The samples were scanned using infrared in the range of 4000-400 cm-1 using Fourier Transform Infrared Spectrometer Nicolet Model-6700 (Thermo Scientific, USA). The spectral data obtained were compared with the reference chart to identify the functional groups present in the sample.

\section{RESULT AND DISCUSSION}

The results of the antimicrobial activity of the leaf extract of Rhynchostylis retusa against some bacterial isolates (Staphylococcus aureus, Escherichia coli, Pseudomonas aeruginosa and Salmonella typhi) are presented in Table 1.

Table 1: Leaf Extracts and their Zone of Inhibition (in mm) / Antimicrobial Activity against Test Organisms

\begin{tabular}{|c|c|c|}
\hline Test Organism & \multicolumn{2}{|c|}{ Plant extracts and their zones of inhibition (mm) } \\
\hline & Fresh leaf extract & Dry leaf extract \\
\hline Staphylococcus aureus & $22.0 \pm 4.0$ & $13.8 \pm 2.4$ \\
\hline Escherichia coli & $20.8 \pm 4.0$ & $14.0 \pm 2.4$ \\
\hline Pseudomonas aeruginosa & $22.4 \pm 4.0$ & $15.0 \pm 2.4$ \\
\hline Salmonella typhi & $20.0 \pm 4.0$ & $12.0 \pm 2.4$ \\
\hline
\end{tabular}

Fresh leaf extract exhibited more antimicrobial activity as compared to dry leaf extract. The antimicrobial efficacy based on inhibition zone diameter (in $\mathrm{mm}$ ) against the bacterial strain Staphylococcus aureus, Escherichia coli, Pseudomonas aeruginosa and Salmonella typhi were recorded as 22.0, 20.8, 22.4 and $20.0 \pm 4.0$, respectively. There was no zone of inhibition in case of distilled water, used as negative control $(0.0 \mathrm{~mm})$. The dry leaf extract had very poor inhibition of bacterial growth. The maximum inhibition was shown against Pseudomonas aeruginosa by the dried leaf extract and it was $15.0 \mathrm{~mm} \pm 2.4 \mathrm{~mm}$. There's a slight variation in the functional groups of the FTIR spectra obtained from fresh and dry leaf extracts (Figure 1, 2).

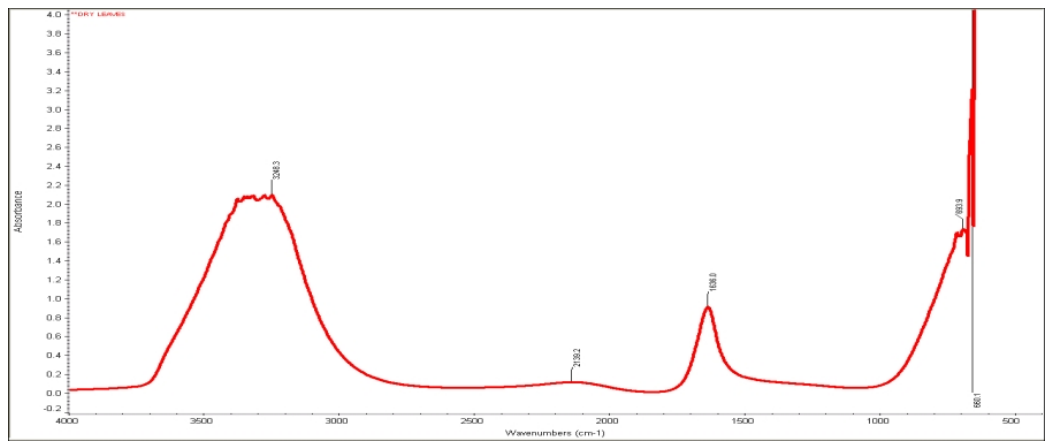

Figure 1: FTIR Analysis of Dried Leaf Extract

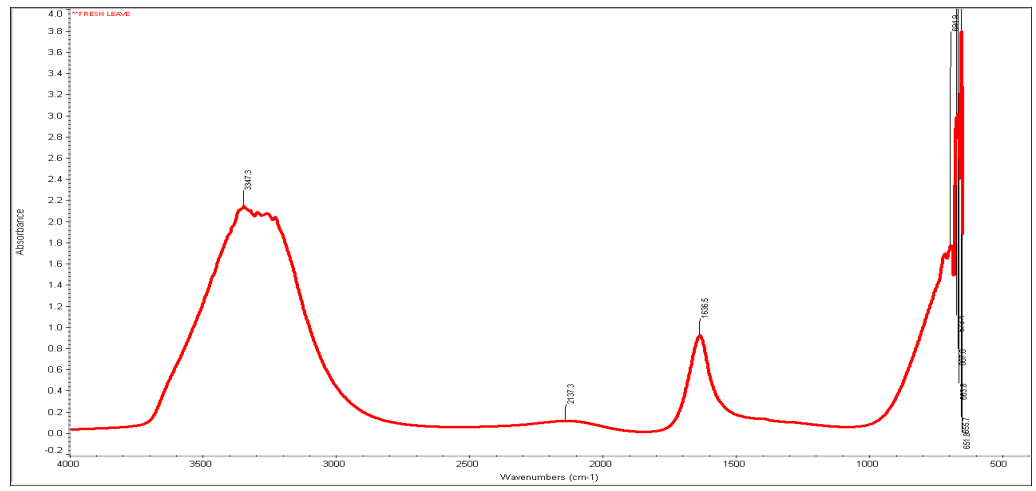

Figure 2: FTIR Analysis of Fresh Leaf Extract 
Alkynyl and Carbonyl peaks are common in case of both the extracts, but there is a variation in sharp peaks of both the extract. Amine peak is observed in case of fresh leaf extract whereas alcohol / phenol peak is observed in case of dry leaf extract. The peaks of the fingerprint region confirmed the presence of respective identified groups, apart from these, numerous new peaks are observed in the finger print region of the fresh leaf extract (Table 2).

Table 2: FTIR Peaks and Functional Groups of Leaf Extracts

\begin{tabular}{|c|c|c|}
\hline Functional Groups & \multicolumn{2}{|c|}{ FTIR Peak Values of both the Extracts $\mathbf{( c m}^{-1} \mathbf{)}$} \\
\hline & Fresh leaf extract & Dry leaf extract \\
\hline Alkynl group & 2137.3 & 2139.3 \\
\hline Carbonyl group & 1636.5 & 1636.0 \\
\hline Amine group & 3347.3 & ------- \\
\hline Alcohol / phenol group & ---------- & 3248.3 \\
\hline
\end{tabular}

\section{CONCLUSION}

The therapeutic value of medicinal plants lies in the various functional groups possessed by the phyto-constituents present in the herb. Antimicrobial activity of fresh leaf was better than dry leaf. This was again confirmed by the variation in the FTIR spectra peaks of both fresh and dry leaf extracts of Rhynchostylis retusa, indicating that phyto-constituent obtained from the fresh leaves remain active due to the presence of amine functional group. Further studies are needed to determine the reasons for loss / changes in this functional group of active ingredient on drying of leaves.

\section{REFERENCES}

1. Pokhrel S, Singh R, Gautam P, Das AJ. Comparison of antimicrobial activity of crude ethanolic extracts and essential oils of spices against five strains of diarrhea causing Escherichia coli. Int J Pharm Life Sc 2012; 3(4): 1624-1627.

2. El Astal ZY, Aera A, Aam A. Antimicrobial activity of some medicinal plant extracts in Palestine. Pak J Med Sc 2005; 21(2): 187.

3. Das AJ, Mohd A. Variation of Antibiotic Sensitivity of Escherichia coli Strain against Norfloxacin among Two Persons. J Pure App Microbiol 2012; 6(1): 387-393.

4. Mohd A, Das AJ. Current trends in drugs discovery: Target identification to clinical development of the drugs. Int Res J Pharm 2012; 3(4): 23-28.

5. Griffiths PR, De Haseth JA. Fourier Transform Infrared Spectroscopy. New York: Wiley; 1986.

6. Md NB, Wesely EG, Johnson M. FTIR studies on the leaves of Albizia lebbeck Benth. Int J Pharm Pharma Sc 2012; 4(3): 293-296.

7. Surewicz WK, Mantsch HH, Chapman D. Determination of Protein Secondary Structure by Fourier Transform Infrared Spectroscopy: A Critical Assessment. Biochem 1993; 32(2): 389-393. http://dx.doi.org /10.1021/bi00053a001

8. Das AJ, Kumar R, Mohd A, Rawat DS. Ethno Medicinal Study of Threatened Plants of Sonitpur district in Assam, North East India. Int Res J Pharm 2013; 4(1): 146-149.

9. Das AJ, Mohd A, Rawat DS, Das PJ. Ethno medicinal survey of medicinal plants used to cure wounds in Darikal gaon of Tezpur in Assam, North East India. Int Res J Pharm 2012; 3(2): 193-195.

10. Das AJ. A study of antibacterial activity of ethanolic extracts and aqueous extracts of Leucas longifolia (Doron) leaves against Escherichia coli. Int Res J Pharm 2012; 3(1): 130-131.

11. Oyagade JO. Antimicrobial efficacy of stem bark extract of Terminalic schimpeliana. Department of Biology Science Research Communication, Unilorin 1998; 9: 143-149.

\section{Cite this article as:}

Das Amar Jyoti, Athar Mohammad, Kumar Manoj and Kumar Rajesh. FTIR analysis for screening variation in antimicrobial activity of fresh and dried leaf extract of Rhynchostylis retusa: A threatened orchid species of Assam, North East India. Int. Res. J. Pharm. 2013; 4(7):187-189 http:// dx.doi.org/10.7897/2230-8407.04741 